\title{
Diatoms as a paleoproductivity proxy in the NW Iberian coastal upwelling system (NE Atlantic)
}

\author{
Diana Zúñiga ${ }^{1,2}$, Celia Santos ${ }^{3,4,5}$, María Froján ${ }^{2}$, Emilia Salgueiro $^{3,5}$, Marta M. Rufino ${ }^{3,5,7}$, Francisco De la Granda ${ }^{6}$, \\ Francisco G. Figueiras ${ }^{2}$, Carmen G. Castro ${ }^{2}$, and Fátima Abrantes ${ }^{3,5}$ \\ ${ }^{1}$ University of Vigo, Applied Physics Department, Campus Lagoas Marcosende, 36310, Vigo, Spain \\ ${ }^{2}$ Consejo Superior de Investigaciones Científicas (CSIC), Instituto de Investigaciones Marinas (IIM), 36208, Vigo, Spain \\ ${ }^{3}$ Instituto Português do Mar e da Atmosfera (IPMA), Div. Geologia e Georecursos Marinhos, 1495-006, Lisbon, Portugal \\ ${ }^{4}$ MARUM, Center for Marine Environmental Sciences, University of Bremen, 28359, Bremen, Germany \\ ${ }^{5}$ CCMAR - Centre of Marine Sciences, Universidade do Algarve, Campus de Gambelas, 8005-139 Faro, Portugal \\ ${ }^{6}$ Federal Maritime and Hydrographic Agency of Germany, 20359, Hamburg, Germany \\ ${ }^{7}$ IFREMER, Centre Atlantique (French Research Institute for Exploitation of the Sea), 44311, Nantes, France \\ Correspondence to: Diana Zúñiga (diana.zuniga@uvigo.es, imissons@gmail.com)
}

Received: 12 May 2016 - Discussion started: 31 May 2016

Revised: 6 February 2017 - Accepted: 23 February 2017 - Published: 13 March 2017

\begin{abstract}
The objective of the current work is to improve our understanding of how water column diatom's abundance and assemblage composition is seasonally transferred from the photic zone to seafloor sediments. To address this, we used a dataset derived from water column, sediment trap and surface sediment samples recovered in the NW Iberian coastal upwelling system.
\end{abstract}

Diatom fluxes $\left(2.2( \pm 5.6) 10^{6}\right.$ valves $\left.\mathrm{m}^{-2} \mathrm{~d}^{-1}\right)$ represented the majority of the siliceous microorganisms sinking out from the photic zone during all studied years and showed seasonal variability. Contrasting results between water column and sediment trap diatom abundances were found during downwelling periods, as shown by the unexpectedly high diatom export signals when diatom-derived primary production achieved their minimum levels. They were principally related to surface sediment remobilization and intense Minho and Douro river discharge that constitute an additional source of particulate matter to the inner continental shelf. In fact, contributions of allochthonous particles to the sinking material were confirmed by the significant increase of both benthic and freshwater diatoms in the sediment trap assemblage.

In contrast, we found that most of the living diatom species blooming during highly productive upwelling periods were dissolved during sinking, and only those resistant to dissolution and the Chaetoceros and Leptocylindrus spp. resting spores were susceptible to being exported and buried. Fur- thermore, Chaetoceros spp. dominate during spring-early summer, when persistent northerly winds lead to the upwelling of nutrient-rich waters on the shelf, while Leptocylindrus spp. appear associated with late-summer upwelling relaxation, characterized by water column stratification and nutrient depletion. These findings evidence that the contributions of these diatom genera to the sediment's total marine diatom assemblage should allow for the reconstruction of different past upwelling regimes.

\section{Introduction}

Diatoms are the most important primary producers in the ocean and play a key role in biogeochemical cycles through transferring organic carbon and biogenic silica from the surface layer to the seafloor sediments (Sancetta, 1989; Romero and Armand, 2010; Tréguer and De La Rocha, 2013). The preservation of their siliceous valves in marine sediment records has promoted their use as paleoproductivity indicators. However, reconstruction of primary production still suffers from diverse uncertainties, indicating that more studies are needed to accurately discern how particular environmental conditions regulate the diatom response and how diatom's ecological traits transfer primary production signals from the water column to the sediments through exported and buried 
particles. In this regard, the analysis of data provided by sediment traps has contributed significantly to improving our knowledge of this topic, because the deployment of traps still is the best approach for monitoring downward diatom fluxes as a response to oceanographic and biological processes occurring in surface waters on a long-term basis.

Coastal upwelling systems are sites with major diatomderived primary production where seasonality is often a noticeable feature (Walsh, 1991; Falkowski et al., 1998; Capone and Hutchins, 2013). Consequently, many studies focused on how primary production signal is exported through the water column in these highly productive coastal regions and were conducted through the analysis of downward diatom flux time series (Sancetta, 1995; Lange et al., 1998; Romero et al., 2002; Abrantes et al., 2002; Venrick et al., 2003; Onodera et al., 2005). In the NW Iberian margin, despite being the most productive upwelling region in Europe (Figueiras and Pazos, 1991; Nogueira and Figueiras, 2005; Espinoza-González et al., 2012), the use of diatoms as a productivity tracer to date was based on a direct comparison of the hydrographic conditions with surface sediment (Abrantes, 1988; Bao et al., 1997; Abrantes and Moita, 1999). From these studies it was concluded that Chaetoceros resting spores could be used as a good tracer of upwelling patterns, in particular the position of the upwelling front. Nevertheless, none of these studies provided information on the processes regulating seasonal diatom production and export from the photic zone to the seafloor sediments. In this context, the aim of this work is to go further in this topic by presenting the first analysis of the diatom community that combines water column, sediment trap and surface sediment samples recorded in this margin. Our results will provide relevant information regarding the use of fossil diatom assemblages as a primary production paleotracer in the highly productive NW Iberian coastal upwelling system.

\section{Regional setting}

Our study site (RAIA station) is located in the NW Iberian continental shelf off Cape Silleiro $\left(42^{\circ} 05^{\prime} \mathrm{N}, 8^{\circ} 56^{\prime} \mathrm{W} ; 75 \mathrm{~m}\right.$ water depth; Fig. 1). During spring-summer, the NW Iberian coast is characterized by prevailing northerly winds that favor upwelling of cold and nutrient-rich subsurface Eastern North Atlantic Central Water (ENACW), resulting in high primary production (Fraga, 1981; Fiuza, 1984; Tenore et al., 1995; Figueiras et al., 2002). In contrast, southwesterly winds favor coastal downwelling during autumn-winter. Hydrographically, from October to January the region is generally affected by the northward advection of warm, saline and nutrient-poor waters by the Iberian Poleward Current (IPC) (Haynes and Barton, 1990; Castro et al., 1997; Relvas et al., 2007). Later on, usually between February and March, a decrease of temperature associated with winter cooling leads to a well-homogenized mixed layer of cold and

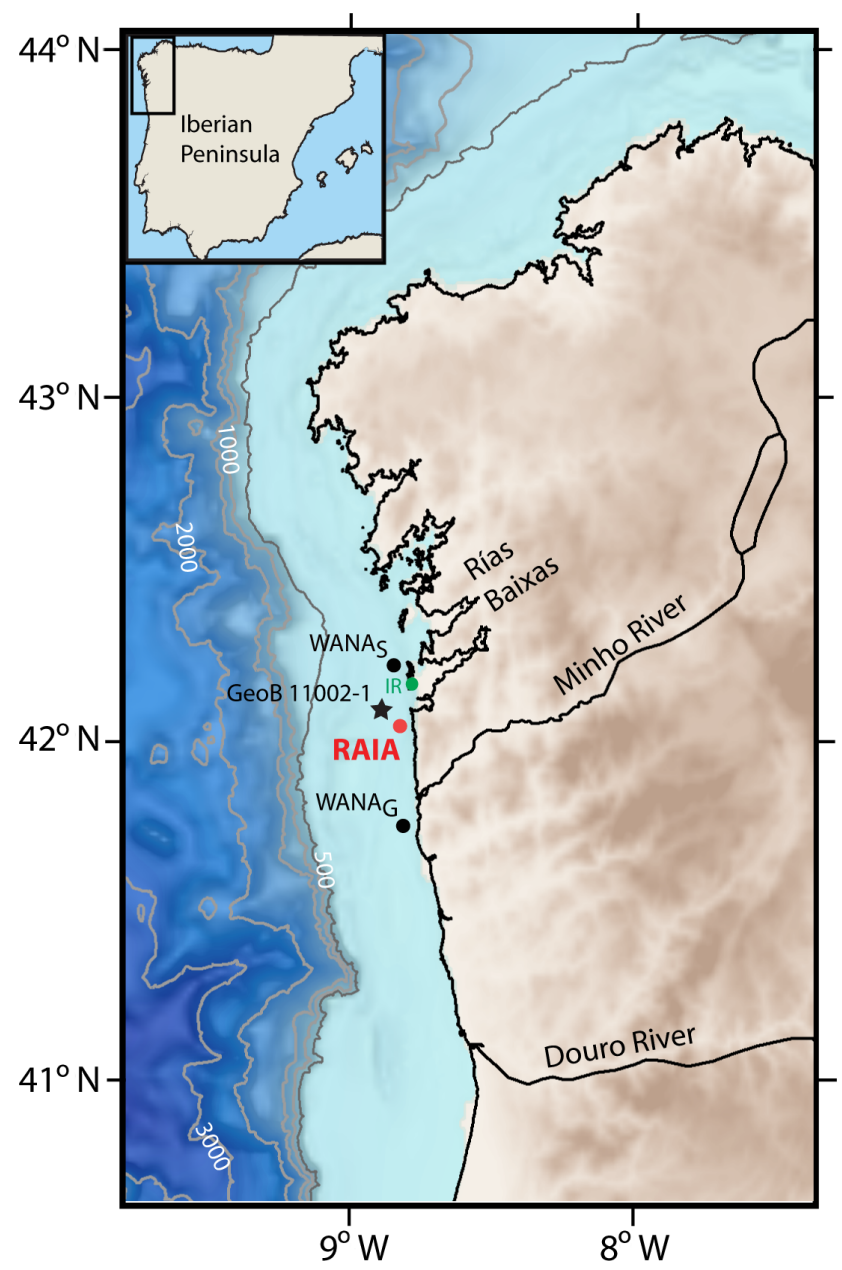

Figure 1. Map of the NW Iberian Peninsula continental margin showing the position of the mooring line (RAIA) site. WANA hind-

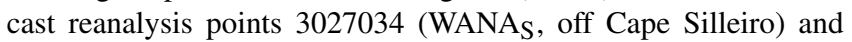
1044067 (WANA $_{\mathrm{G}}$, off A Guarda) from which wave data were obtained, location of the irradiance Cíes station (IR) and position of the core-top sediment sample GeoB11002-1 are also shown.

nutrient-rich waters (Álvarez-Salgado et al., 2003; Castro et al., 2006). In addition, during downwelling seasons, the occurrence of southwesterly winds can generate moderate to extreme storms with wave heights $>6 \mathrm{~m}$, which have been simulated to produce high sediment remobilization (Vitorino et al., 2002; Jouanneau et a., 2002; Oberle et al., 2014). During these highly energetic periods, this region is also strongly influenced by the discharge of the Minho and Douro rivers (annual averages of 550 and $310 \mathrm{~m}^{3} \mathrm{~s}^{-1}$, respectively), which is an important source of terrestrial sediment to the inner shelf. This mainly occurs during the winter months, when river inflow can reach $3850 \mathrm{~m}^{3} \mathrm{~s}^{-1}$ for the Douro River and $1800 \mathrm{~m}^{3} \mathrm{~s}^{-1}$ for the Minho River (Dias et al., 2002; Otero et al., 2010). 


\section{Material and methods}

\subsection{External forcing}

Irradiance data were obtained from Cíes Islands meteorological station (IR; $42^{\circ} 13^{\prime} \mathrm{N}, 8^{\circ} 54^{\prime} \mathrm{W} ; 25 \mathrm{~m}$ height) (Fig. 1) and are available through the MeteoGalicia website (www. meteogalicia.es).

The upwelling index (UI), an estimate of the volume of upwelled water per kilometer of coast, was calculated according to Bakun's (1973) method:

$\mathrm{UI}=-\left(\left(\rho_{\mathrm{a}} C_{\mathrm{D}}|V|\right) /\left(f \rho_{\mathrm{sw}}\right)\right) V_{y}$,

where $\rho_{\mathrm{a}}$ is the density of the air $\left(1.22 \mathrm{~kg} \mathrm{~m}^{-3}\right)$ at $15^{\circ} \mathrm{C}, C_{\mathrm{D}}$ is an empirical dimensionless drag coefficient $\left(1.4 \times 10^{-3}\right)$, $f$ is the Coriolis parameter $\left(9.76 \times 10^{-5} \mathrm{~s}^{-1}\right)$ at $42^{\circ} \mathrm{N}, \rho_{\mathrm{sw}}$ is the seawater density $\left(1025 \mathrm{~kg} \mathrm{~m}^{-3}\right)$ and $|V|$ and $V_{y}$ are the average daily module and northerly component of the geostrophic winds $\left(\mathrm{m} \mathrm{s}^{-1}\right)$ centered at $42^{\circ} \mathrm{N}, 10^{\circ} \mathrm{W}$, respectively. Positive values show the predominance of northerly winds that induces upwelling on the shelf and negative values indicate the presence of downwelling. Minho and Douro river discharge was obtained from https://github.com/ PabloOtero/uptodate_rivers (Otero et al., 2010). Significant wave height data were based on WANA hindcast reanalysis of 3027034 (WANA $_{S}$, off Silleiro: $42^{\circ} 15^{\prime} \mathrm{N}, 9^{\circ} \mathrm{W}$ ) and 1044067 (WANA $_{\mathrm{G}}$, off A Guarda: $41^{\circ} 45^{\prime} \mathrm{N}, 9^{\circ} \mathrm{W}$ ) (Fig. 1) points and supplied by Puertos del Estado (www.puertos.es).

\subsection{Water column}

RAIA station (75 m water depth) was visited monthly by R/V Mytilus from March 2009 to June 2012 except during the period December 2009-June 2010. Characterization of the water column was conducted by (i) CTD-SBE25 profiling and (ii) collection of discrete water column samples at $5 \mathrm{~m}$ water depth using a rosette sampler (10 L PVC Niskin bottles). Aliquots of these samples were used for inorganic nutrients, chlorophyll $a(\mathrm{Chl} a)$ and diatoms counting/species identification analysis.

Water column stability $(0-35 \mathrm{~m})$ was analyzed by using Brunt-Väisälä frequency parameter, $N^{2}=[g / z] \ln \left(\rho_{z} / \rho_{0}\right)$ where $g$ is the local acceleration of gravity, $\mathrm{z}$ is the water depth and $\rho_{z}$ and $\rho_{0}$ are the bottom and surface density, respectively.

Inorganic nutrient concentrations were determined by segmented flow analysis with Alpkem autoanalyzers (Hansen and Grasshoff, 1983). The analytical errors were $\pm 0.05 \mu \mathrm{mol} \mathrm{kg}{ }^{-1}$ for nitrate and silicate and $\pm 0.01 \mu \mathrm{mol} \mathrm{kg}^{-1}$ for phosphate. Final Chl $a$ concentrations were determined by pigment extract fluorescence using a Turner Designs fluorometer calibrated with pure Chl $a$ (see details in Zúñiga et al., 2016).

For diatom counting and identification a volume of $100 \mathrm{~mL}$ sample was used. The samples were preserved with
Lugol's iodine until microscopic observation. Depending on the water column, $\mathrm{Chl} a$ concentration volumes between 10 and $50 \mathrm{~mL}$ were deposited in composite sedimentation chambers for observation through an inverted microscope. The microorganisms were counted and identified to the species level, whenever possible, using the Utermöhl sedimentation method (Utermöhl, 1931, 1958). Centric diatom cells whose diameter did not allow for species identification were grouped as small centric diatoms. Only diatom species that appeared in more than one sample with a percentage higher than $2 \%$ of the total abundance were considered for further analysis.

\subsection{Sediment trap}

At RAIA station an automated cylindric-conical Technicap PPS $4 / 3$ sediment trap (height/diameter ratio of 1.7 and a collecting area of $0.05 \mathrm{~m}^{2}$ ) was deployed at $35 \mathrm{~m}$ water depth from March 2009 to June 2012. Sampling intervals ranged from 4 to 12 days. Unfortunately some data were lost due to technical problems and bad weather conditions (Zúniga et al., 2016). Examination of CTD pressure data mounted $2 \mathrm{~m}$ below the trap showed that the mooring line tilting was less than $5^{\circ}$ during $70 \%$ of the time it was deployed. Only in exceptional hydrodynamic events that led to velocities higher than $25 \mathrm{~cm} \mathrm{~s}^{-1}$ was the mooring tilted $15-20^{\circ}$. Therefore, we assume the sediment trap was not affected by hydrodynamic biases. Sampling strategy and sample processing details are explained at length in Zúñiga et al. (2016).

Total mass flux was gravimetrically determined. Biogenic silica content was analyzed following Mortlock and Froelich (1989). The samples were treated with $2 \mathrm{M} \mathrm{Na}_{2} \mathrm{CO}_{3}$ for $5 \mathrm{~h}$ at $85^{\circ} \mathrm{C}$ to extract the silica and then measure as dissolved silica by colorimetric reaction. Biogenic silica was converted from Si concentration after multiplying it by a factor of 2.4 .

Sample preparation for diatom abundance and assemblage assessment was adapted from Abrantes et al. (2005). Depending on the recovered material one-fifth or twofifth splits of the original samples were used, after $\mathrm{HgCl}_{2}$ rinse by repeated settling in distilled water. Subsequently, organic matter and carbonates were removed by the addition of $\mathrm{H}_{2} \mathrm{O}_{2}(30 \%)$ and $\mathrm{HCl}(10 \%)$, respectively. Permanent slides were prepared using the evaporation-tray method of Battarbee (1973) and Norland optical adhesive (NOA61) as the mounting medium. Diatoms counting and species identification was performed at $1000 \times(10 \times$ eyepieces and $100 \times$ objectives), using a Nikon Eclipse E100 microscope equipped with differential interference contrast (DIC). One hundred randomly selected fields of view were counted in three replicate slides (Abrantes et al., 2005). The diatom flux was calculated as follows:

$F=((N)(A / a)(V)(S)(X)) / D$, 


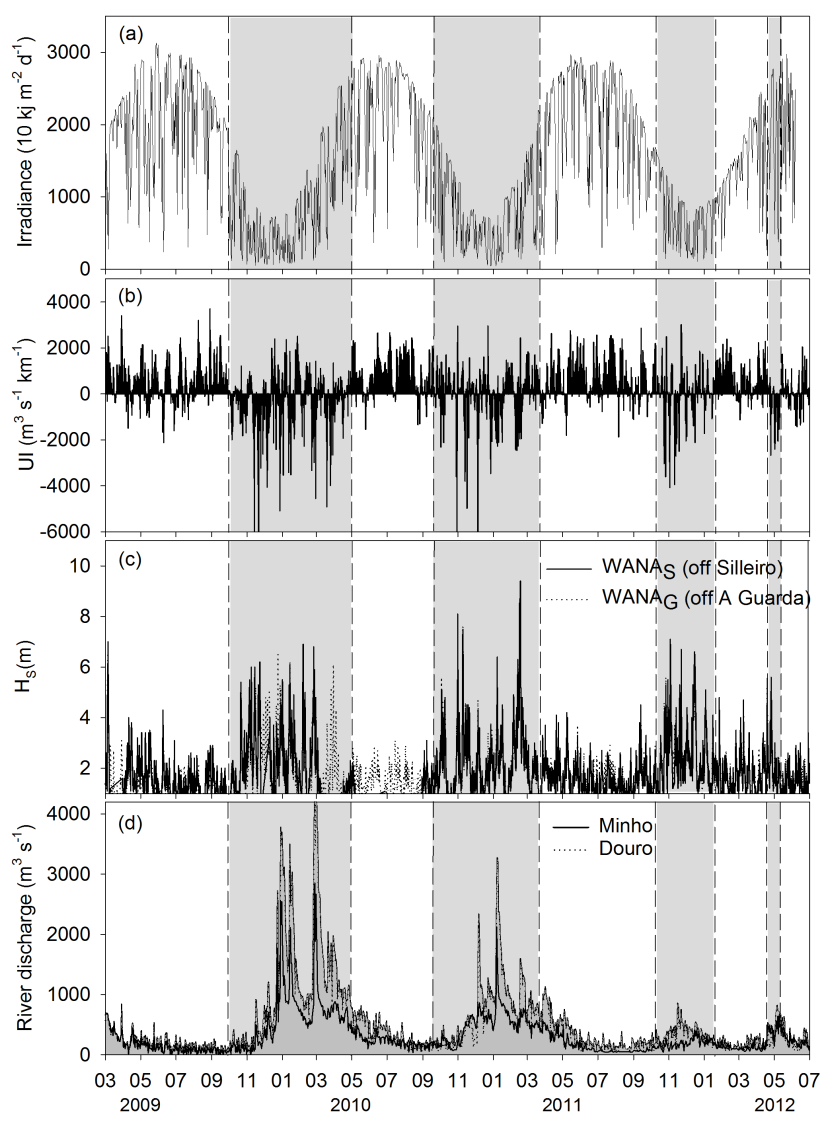

Figure 2. Temporal series of (a) total irradiance at Cíes Islands station (IR), (b) upwelling index (UI), (c) significant wave heights $\left(H_{\mathrm{S}}\right)$ obtained from the points off Silleiro and off A Guarda WANA and (d) Minho and Douro river discharge. Upwelling and downwelling periods are highlighted with white and grey bars, respectively, based on upwelling index and biogeochemical data presented in Zúñiga et al. (2016).

where the flux $F$ is expressed as number of valves $\mathrm{m}^{-2} \mathrm{~d}^{-1}$, $N$ is the number of valves counted in 100 randomly selected fields of view, $(a)$ represents the counted fraction of the total tray area $(A), V$ is the dilution volume, $S$ is the split fraction, $X$ is the conversion factor from the collecting area to $1 \mathrm{~m}^{2}$, and $D$ is the sampling interval in days for each sample.

Relative abundance of diatom taxa was determined following the counting procedures from Schrader and Gersonde (1978) and Abrantes (1988). For each sample, ca. 300 individuals were identified to the lowest taxonomic possible level, and raw counts were converted to percentage abundance. In samples containing low diatom abundances, the number of individuals identified was 100-200 (Fatela and Taborda, 2002). For this study only diatom species that appeared in more than one sample with a percentage higher than $2 \%$ of the total abundance were considered for further analysis.

\subsection{Surface sediments}

To evaluate the sedimentary record, we used one core-top sediment $(0-1 \mathrm{~cm})$ from box-core GeoB $11002-1\left(42^{\circ} 10^{\prime} \mathrm{N}\right.$, $8^{\circ} 58^{\prime} \mathrm{W} ; 111 \mathrm{~m}$ ) recovered near the RAIA position (Fig. 1). The sample was collected in August 2006, using a giant box corer during the GALIOMAR expedition (P342) on board of the R/V Poseidon. Sample cleaning and slides preparation was carried out following the methodology of Abrantes et al. (2005). Counting and identification procedures were the same as for sediment traps samples.

\subsection{Statistical data analysis}

Relationships between environmental variables and sediment trap diatom species relative abundances were evaluated with Pearson correlation coefficients and presented in Table 1 and 2 , respectively.

In addition, the relationship between the relative abundance of the main groups of diatoms (freshwater (FW) diatoms, benthic diatoms, Chaetoceros resting spores, Leptocylindrus resting spores and Paralia sulcata) and the environmental variables were analyzed using the ordination technique canonical correspondence analysis (CCA) (vegan package, R-project; ter Braak, 1986; Oksanen et al., 2015). The water column environmental data were at first monthly interpolated and later averaged for the time interval recovered by each trap sample. Resulting data were subsequently integrated to $35 \mathrm{~m}$ where the sediment trap was moored. The multicollinearity of environmental variables was previously tested by Pearson correlations (Dormann et al., 2013) and checked after modeling using variance inflation factors (VIFs) applied to the CCA. Nine environmental variables were thus initially included in the ordination: irradiance, temperature, Brunt-Väisälä frequency parameter $\left(N^{2}\right)$, Chl $a, \mathrm{NO}_{3}, \mathrm{Si}(\mathrm{OH})_{4}$, UI, Minho River flow, A Guarda wave height $\left(H_{\mathrm{s}}\right)$. Significant environmental variables were identified via a stepwise procedure, using permutation tests (999 permutations). After the selection of the significant variables, the model was tested a second time through a Monte Carlo global permutation test (999 permutations) to assess the significance of ordination axes.

The results of CCA were presented as ordination biplot diagram containing the explanatory variables plotted as arrows along with points for samples (dates) and species (main groups of diatoms). Using these diagrams, we were able to identify the relationships between species and between samples, as well as relationships of samples and species to environmental variables. Surface sediment sample location on the ordination plot was predicted using the CCA model produced with the sediment trap samples. 
Table 1. Environmental variables matrix Pearson correlations. Irrad: irradiance; Temp: temperature; Sal: salinity; $N^{2}$ : Brunt-Väisälä frequency parameter; Chl $a$ : chlorophyll $a$; SPM: suspended particulate matter; POC: particulate organic carbon; UI: upwelling index; Minho: Minho River discharge; Waves: Significant wave height off A Guarda (WANA ${ }_{G}$ ) station.

\begin{tabular}{|c|c|c|c|c|c|c|c|c|c|c|c|c|c|c|}
\hline & Irrad & Temp & Sal & $\mathrm{N}^{2}$ & $\mathrm{Chl} a$ & SPM & POC & $\mathrm{NO}_{3}$ & $\mathrm{PO}_{4}$ & $\mathrm{Si}(\mathrm{OH})_{4}$ & Oxygen & UI & Minho & Waves \\
\hline Irrad & 1.00 & -0.394 & 0.487 & -0.0827 & 0.528 & -0.555 & 0.376 & 0.0167 & 0.0764 & -0.642 & 0.148 & 0.487 & -0.236 & -0.357 \\
\hline Temp & & 1.00 & -0.263 & 0.616 & -0.196 & 0.332 & 0.184 & -0.284 & -0.195 & 0.351 & -0.346 & -0.456 & 0.0961 & 0.0557 \\
\hline Sal & & & 1.00 & -0.0509 & 0.228 & -0.645 & 0.348 & 0.0839 & 0.263 & -0.841 & -0.137 & 0.518 & -0.689 & -0.27 \\
\hline $\mathrm{N}^{2}$ & & & & 1.00 & -0.284 & 0.249 & 0.124 & -0.266 & 0.0559 & 0.0825 & -0.38 & -0.266 & -0.101 & -0.0122 \\
\hline Chl $a$ & & & & & 1.00 & -0.476 & 0.355 & 0.0608 & -0.0003 & -0.321 & 0.124 & 0.205 & 0.0433 & -0.272 \\
\hline SPM & & & & & & 1.00 & -0.104 & 0.153 & 0.0953 & 0.79 & -0.223 & -0.409 & 0.334 & 0.257 \\
\hline POC & & & & & & & 1.00 & 0.24 & 0.341 & -0.201 & -0.39 & 0.0841 & -0.246 & -0.242 \\
\hline $\mathrm{NO}_{3}$ & & & & & & & & 1.00 & 0.871 & 0.287 & -0.677 & 0.182 & -0.106 & -0.252 \\
\hline $\mathrm{PO}_{4}$ & & & & & & & & & 1.00 & 0.137 & -0.823 & 0.233 & -0.274 & -0.185 \\
\hline $\mathrm{Si}(\mathrm{OH})_{4}$ & & & & & & & & & & 1.00 & -0.297 & -0.466 & 0.523 & 0.240 \\
\hline Oxygen & & & & & & & & & & & 1.00 & 0.0592 & 0.213 & 0.204 \\
\hline UI & & & & & & & & & & & & 1.00 & -.0394 & -0.116 \\
\hline Minho & & & & & & & & & & & & & 1.00 & 0.139 \\
\hline Waves & & & & & & & & & & & & & & 1.00 \\
\hline
\end{tabular}

Table 2. Pearson correlation matrix for the sediment trap diatom species relative abundances (\%). FW: freshwater diatoms; ChaetoRS: Chaetoceros spp. resting spores; Cos.mar: Coscinodiscus marginatus; Cos.rad: Coscinodiscus radiatus; LeptoRS: Leptocylindrus spp. resting spores; Nav: Navicula; Nitzs.mar: Nitzschia marina; Par.sulc: Paralia sulcata; Pse.Pun: Pseudo-nitzschia pungens; Thal.ecc: Thalassiosira eccentrica; Thal.nitzs: Thalassionema nitzschioides.

\begin{tabular}{|c|c|c|c|c|c|c|c|c|c|c|c|c|}
\hline & FW & Benthic & ChaetoRS & Cos.mar & Cos.rad & LeptoRS & Nav.spp & Nitzs.mar & Par.sulc & Pse.pun & Thal.ecc & Thal.nitzs \\
\hline FW & 1.00 & 0.482 & -0.0085 & -0.312 & 0.161 & 0.226 & -0.126 & 0.176 & 0.293 & 0.0318 & 0.382 & -0.0879 \\
\hline Benthic & & 1.00 & -0.38 & 0.267 & 0.51 & -0.377 & 0.2 & 0.0623 & 0.671 & 0.159 & 0.428 & 0.0777 \\
\hline ChaetoRS & & & 1.00 & -0.315 & -0.388 & -0.0163 & -0.147 & -0.389 & -0.493 & -0.318 & -0.337 & -0.214 \\
\hline Cos.mar & & & & 1.00 & 0.416 & -0.137 & 0.517 & -0.138 & 0.201 & 0.15 & 0.182 & 0.253 \\
\hline Cos.rad & & & & & 1.00 & 0.283 & 0.267 & 0.0427 & 0.487 & 0.0773 & 0.261 & 0.202 \\
\hline LeptoRS & & & & & & 1.00 & -0.224 & -0.107 & -0.495 & -0.185 & -0.0972 & -0.173 \\
\hline Nav.spp & & & & & & & 1.00 & -0.0424 & 0.196 & 0.18 & 0.074 & 0.174 \\
\hline Nitzs.mar & & & & & & & & 1.00 & 0.173 & 0.547 & 0.338 & 0.079 \\
\hline Par.sulc & & & & & & & & & 1.00 & 0.113 & 0.288 & 0.0748 \\
\hline Pse.pun & & & & & & & & & & 1.00 & 0.412 & 0.561 \\
\hline Thal.ecc & & & & & & & & & & & 1.00 & 0.451 \\
\hline Thal.nitzs. & & & & & & & & & & & & 1.00 \\
\hline
\end{tabular}

\section{Results}

\subsection{Environmental conditions and water column characteristics}

From October to April-May, the NW Iberian margin was characterized by the prevalence of low irradiance levels and southwesterly winds as shown by the negative UI values (Fig. 2a and b). During these periods the region was strongly affected by strong SW storms promoting wave heights higher than $4 \mathrm{~m}$ and intense Minho and Douro river discharge (Fig. 2c and d). As explained in detail in Zúñiga et al. (2016), hydrographically we can distinguish in a first phase the presence of the IPC (October-January), characterized by anomalously warm water $\left(15-17^{\circ} \mathrm{C}\right)$ with relatively low nutrient concentrations and $\mathrm{Chl} a\left(<4 \mathrm{mg} \mathrm{m}^{-3}\right)$ (Fig. 3). Later on, we differentiate the mixing period (from February to April-May), with temperatures of around $14{ }^{\circ} \mathrm{C}$ (due to winter cooling) and higher nutrient levels associated with in- tense river discharge (Figs. 2d, 3a and b, Table 1). During downwelling periods, diatom abundances ranged from 5 to $135 \mathrm{cel} \mathrm{mL}^{-1}$ with small centric diatoms accounting for the largest shares $(52 \pm 25 \%)$ (Figs. 3c, $4 \mathrm{~b}$ and Table 3). Only sporadically were Navicula spp. and Paralia sulcata highly abundant (Fig. 4). In contrast, from April-May to October, the margin was characterized by high irradiance levels and the upwelling of cold $\left(<14^{\circ} \mathrm{C}\right)$ and nutrient-rich ENACW on the continental shelf that led to the development of $\mathrm{Chl} a$ maxima (Figs. 2a, b and 3). During these highly productive upwelling periods, diatom abundances were high (up to $7629 \mathrm{cel} \mathrm{mL}^{-1}$ ) (Fig. 3c). The predominant diatoms in the water column alternated between Chaetoceros spp. at the onset of the upwelling season and Leptocylindrus spp. during the relaxation of the upwelling event when the water column became stratified (Fig. 4e and f). Other species frequently associated with upwelling favorable conditions (e.g., Asterionellopsis glacialis, Detonula pumila or Guinardia deli- 


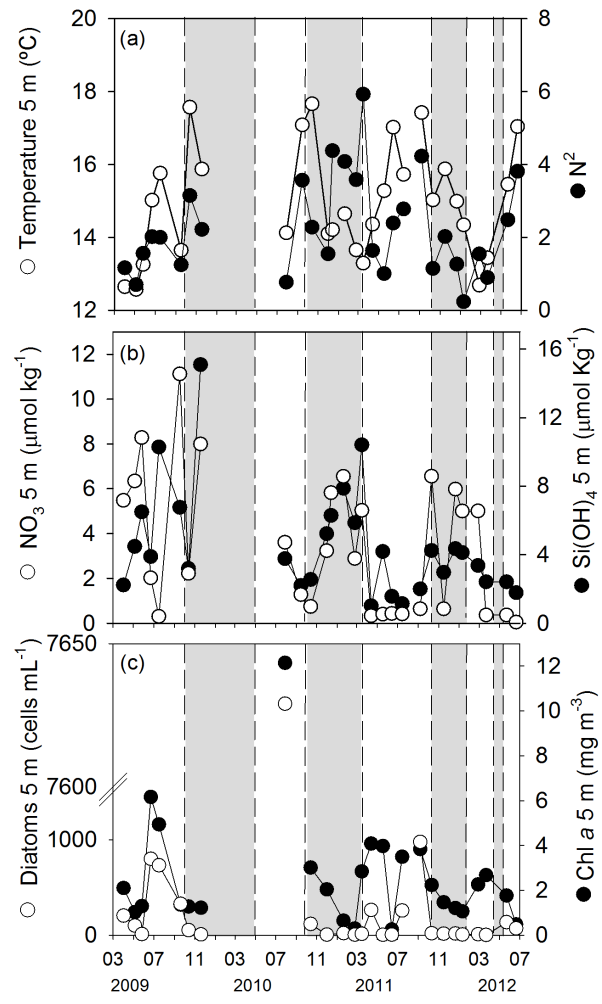

Figure 3. Temporal series of (a) temperature and water column integrated Brunt-Väisälä frequency $\left(N^{2}\right)$, (b) nitrates $\left(\mathrm{NO}_{3}\right)$ and silicates $\left(\mathrm{Si}(\mathrm{OH})_{4}\right)$ content and (c) diatoms abundance and $\mathrm{Chl} a$ concentration, measured on samples recovered at $5 \mathrm{~m}$ water depth. Upwelling and downwelling periods are highlighted with white and grey bars, respectively, based on upwelling index and biogeochemical data presented in Zúñiga et al. (2016).

catula) appeared sporadically and with lower abundances (Fig. 4g, $\mathrm{h}$ and Table 3).

\subsection{Sinking particulate material time series}

The biogenic silica flux time series that ranged between 7 and $1001 \mathrm{mg} \mathrm{m}^{-2} \mathrm{~d}$, contributed from 2 to $10 \%$ of the total material, and was closely follow by the siliceous organism fluxes calculated from microscopic counting (Fig. 5a, b and c). The contribution of diatoms to total siliceous microorganisms dominated throughout the entire period (Fig. 5c and e). Only during the 2012 upwelling season did silicoflagellates become relevant, achieving a relative abundance $>7 \%$ (Fig. 5d). Maximum total diatom fluxes were registered under downwelling conditions (Fig. 5e). During these periods benthic and FW diatoms became relevant, contributing to the total diatom fluxes up of 24 and $17 \%$, respectively (Fig. 6). In contrast, during upwelling phases total diatom fluxes were relatively low, ranging around a mean seasonal value of $6 \pm 10 \times 10^{5}$ valves $\mathrm{m}^{-2} \mathrm{~d}^{-1}$ (Fig. 5e and Table 3). During these periods, the diatom assemblage found in the trap samples were mainly composed of Chaetoceros spp. and

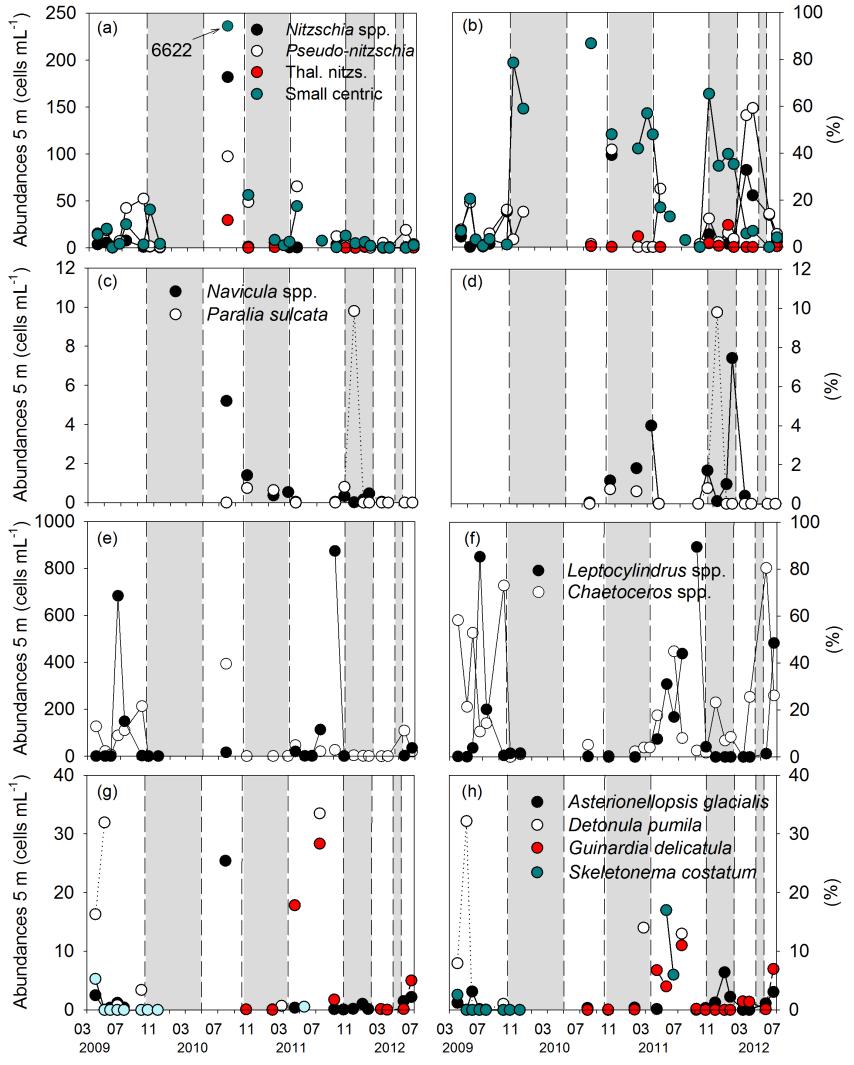

Figure 4. Time series of water column diatom abundances (a, c, e, g) and assemblages (b, d, f, h) from water column samples recovered at $5 \mathrm{~m}$ water depth. Water column diatom species were grouped in order to easily compare them with fossil diatom assemblage from the sediment trap samples. Nitzschia spp: Nitzschia longissima; Pseudo-nitzschia spp: Pseudo-nitzschia cf. delicatissima and Pseudo nitzschia cf. seriata; Thal. nitzs: Thalassionema nitzschioides; small centric includes centric diatom cells whose diameter did not allow for species identification and Thalassiosira spp. small; Navicula spp: Navicula transitans var. derasa; Chaetoceros (Ch.) spp: Ch. curvisetus, Ch. socialis, Ch. didymus, Ch. laciniosus, Ch. decipiens and small Chaetoceros; Leptocylindrus spp: Leptocylindrus danicus. Upwelling and downwelling periods are highlighted with white and grey bars, respectively, based on upwelling index and biogeochemical data presented in Zúñiga et al. (2016). The number and the corresponding arrow in Fig. 4a refer to small centric cells abundance in July 2010.

Leptocylindrus spp. resting spores, with mean contributions to total marine diatom fluxes of 46 and $20 \%$, respectively (Fig. 7 and Table 3).

\subsection{Surface sediment samples}

Diatom abundances in GeoB 11002-1 top sediment sample was $14 \times 10^{5}$ valves $^{-1}$. Marine diatom assemblage was dominated by resting spores of both Chaetoceros (33\%) and Leptocylindrus (37\%) spp., as well as Paralia sulcata (17\%) (Table 3). Benthic and FW diatoms had contributions $<4 \%$. 


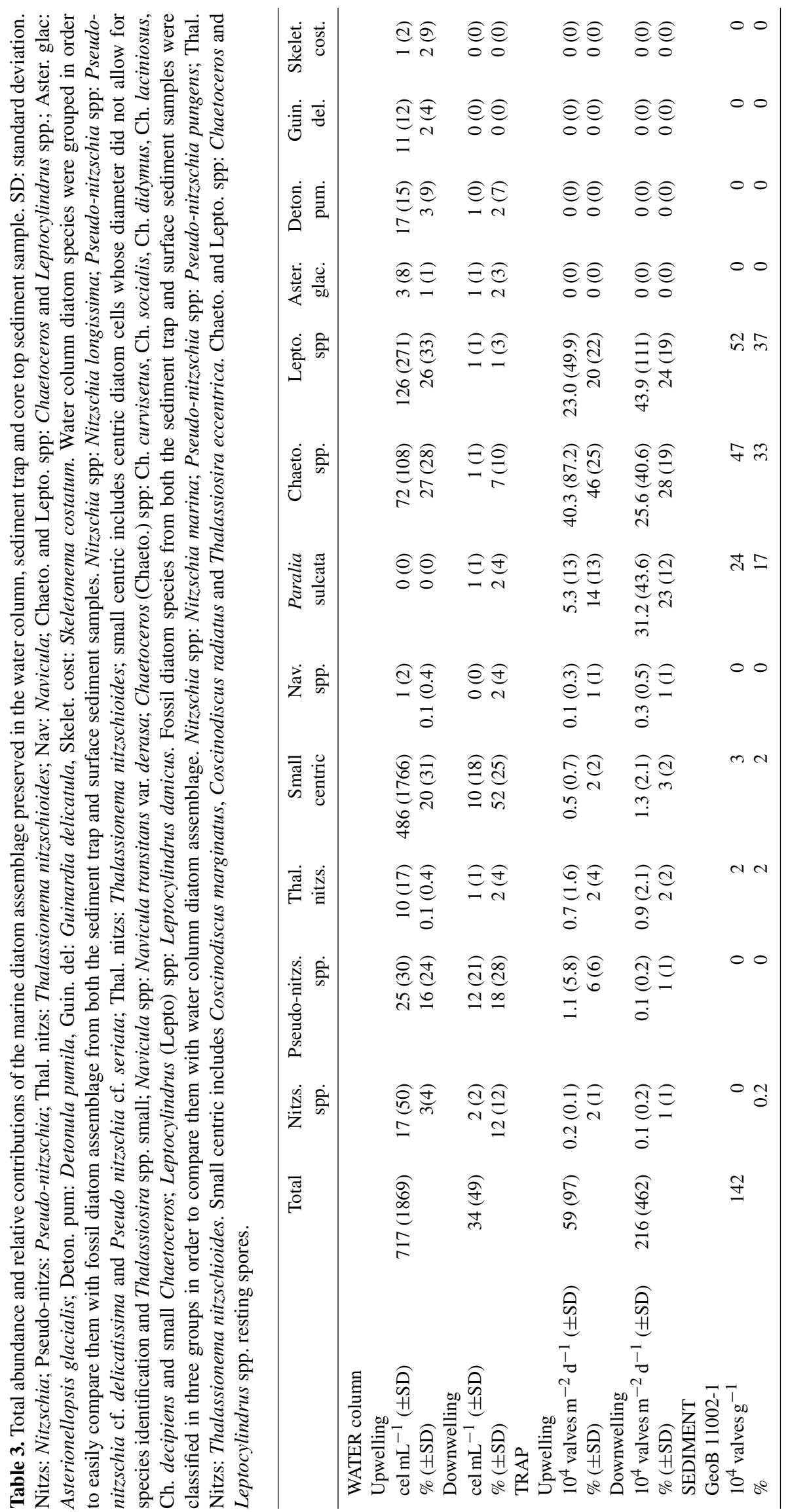




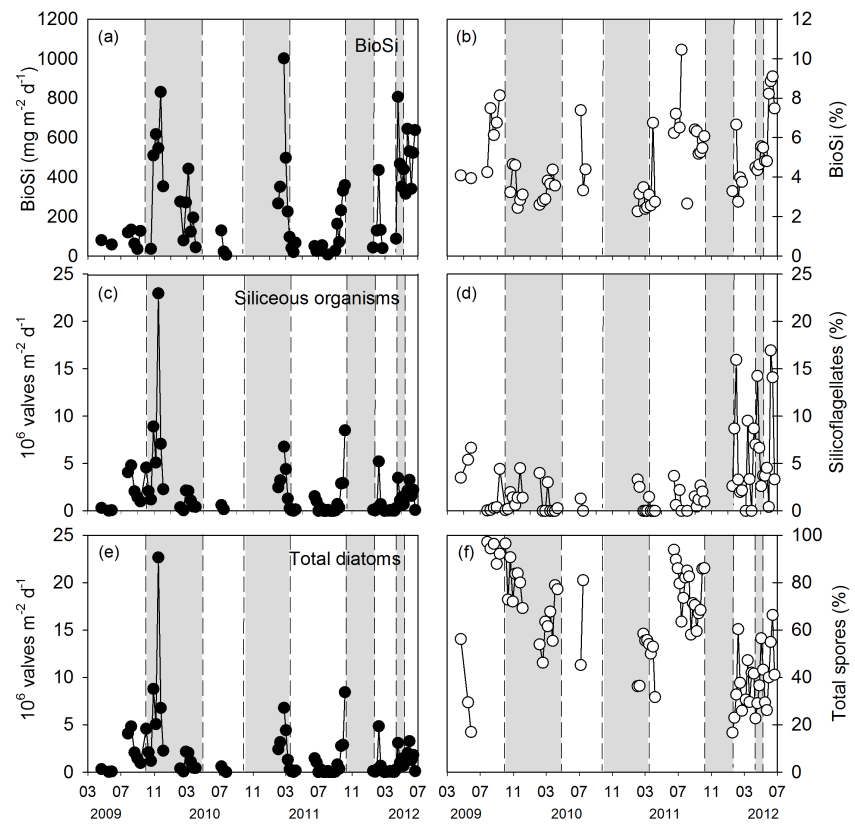

Figure 5. Time series of (a) biogenic silica (BioSi), (c) total siliceous organisms and (e) total diatom (including valves and resting spores) fluxes recorded with a PPS $4 / 3$ sediment trap at RAIA station. Relative contribution of (b) biogenic silica to total mass flux, (d) silicoflagellates respect to total siliceous organisms and (f) resting spores to total diatoms flux is also presented. Upwelling and downwelling periods are highlighted with white and grey bars, respectively, based on upwelling index and biogeochemical data presented in Zúñiga et al. (2016).

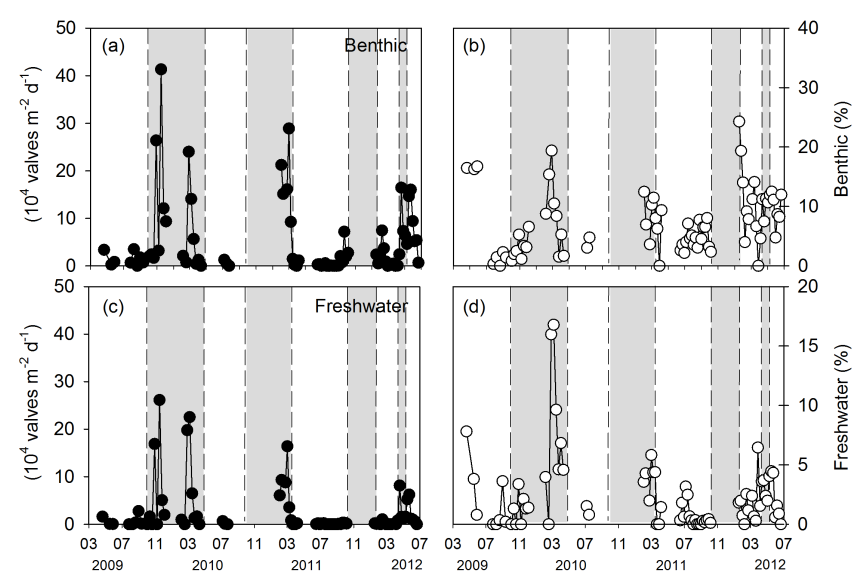

Figure 6. Time series of (a) benthic and (c) freshwater diatom fluxes (and relative contributions respect to total diatoms $\mathbf{b}, \mathbf{d}$ ) recorded with a PPS $4 / 3$ sediment trap at RAIA station. Upwelling and downwelling periods are highlighted with white and grey bars, respectively, based on upwelling index and biogeochemical data presented in Zúñiga et al. (2016).

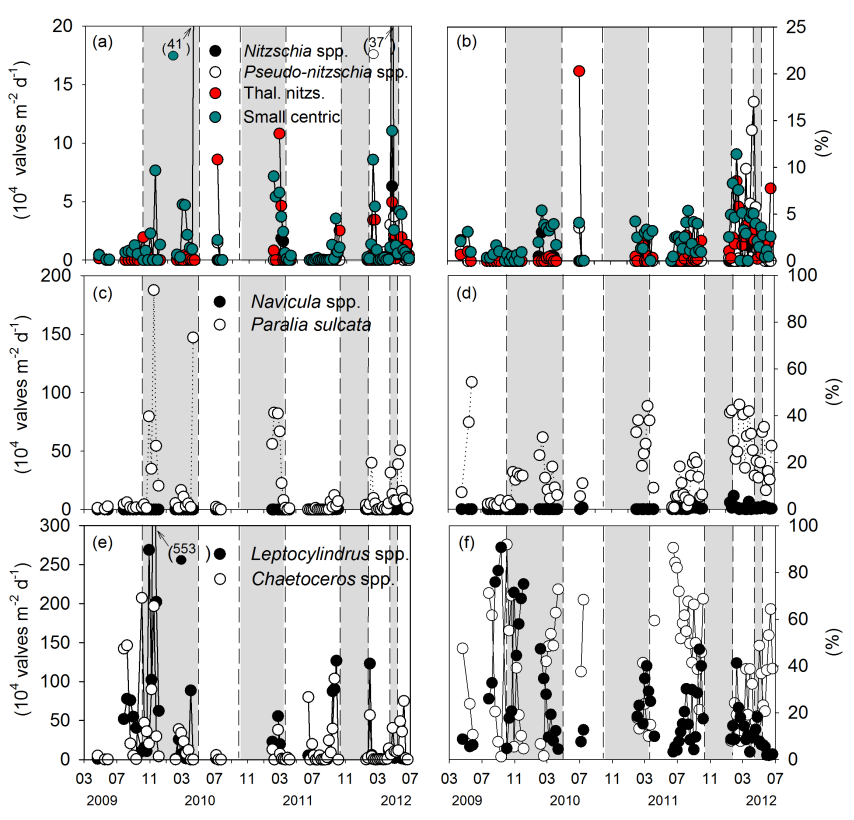

Figure 7. Time series of marine diatoms fluxes $(\mathbf{a}, \mathbf{c}, \mathbf{e})$ and assemblages (relative contributions to total marine diatoms $\mathbf{b}, \mathbf{d}, \mathbf{f}$ ) recorded with a PPS 4/3 sediment trap at RAIA station. Fossil diatom species has been classified in three groups in order to compare them with water column diatom assemblage. Nitzschia spp: Nitzschia marina; Pseudo-nitzschia spp: Pseudo-nitzschia pungens; Thal. Nitzs: Thalassionema nitzschioides. Small centric includes Coscinodiscus marginatus, Coscinodiscus radiatus and Thalassiosira eccentrica. Upwelling and downwelling periods are highlighted with white and grey bars, respectively, based on upwelling index and biogeochemical data presented in Zúñiga et al. (2016).

\subsection{Relationships between sediment trap main diatom groups and environmental variables}

CCA stepwise procedure identified five significant variables for the abundance of the main diatom groups ( $p$ value $<0.05$ ), Minho River flow (Minho River), temperature (Temp), Chl $a, \mathrm{NO}_{3}$ and $\mathrm{Si}(\mathrm{OH})_{4}$ (Fig. 8). The first two canonical axes explained 48.7 and $40.4 \%$, i.e., $89 \%$ of the modeled inertia, and consequently only those two axes were considered. The CCA model with the five variables explained $46 \%$ of the total inertia. The first canonical axis showed a positive gradient with Temp and Chl $a$, opposite to Minho River discharge. FW diatoms, benthic diatoms and Paralia sulcata (Parsul) were negatively positioned in the first canonical axis, thus indicating a positive relationship with the Minho River and a negative relationship with Temp and Chl $a$. The second canonical axis showed a negative gradient with $\mathrm{NO}_{3}$ and $\mathrm{Si}(\mathrm{OH})_{4}$ and a negative relationship between these variables and Chaetoceros resting spores (ChaeRS). Conversely, Leptocylindrus resting spores (LepRS) were positively related with $\mathrm{NO}_{3}$ and $\mathrm{Si}(\mathrm{OH})_{4}$. The temporal distribution of the sediment trap samples confirmed that FW diatoms, benthic diatoms and 


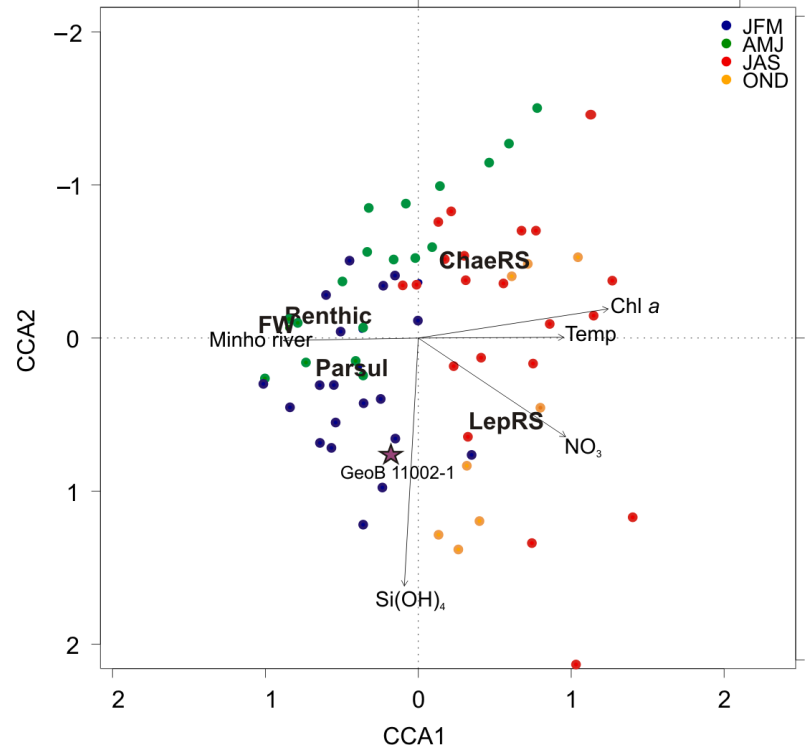

Figure 8. RDA biplot results of the canonical ordination (only significant variables shown) for main fossil sediment trap diatom groups (freshwater (FW) diatoms, benthic diatoms, Paralia sulcata (Parsul), Chaetoceros spp. spores (ChaeRS) and Leptocylindrus spp. spores (LepRS), and forward-selected environmental variables (chlorophyll $a(\mathrm{Chl} a)$, temperature (Temp), nitrates $\left(\mathrm{NO}_{3}\right)$ and silicates $\left(\mathrm{Si}(\mathrm{OH})_{4}\right)$ and Minho River flow). JFM: January-February-March; AMJ: April-May-June; JAS: JulyAugust-September; OND: October-November-December. Position of the predicted surface sediment sample GEOB 11002-1 is also shown.

Parsul occurred mainly during downwelling months, while ChaeRS and LepRS were associated with upwelling periods (Fig. 8). In addition, this figure also identifies LepRS with late-summer periods. The position of the core top sample (GEOB 11001-2) on the CCA ordination reflected an integration between upwelling and downwelling seasonal processes (Fig. 8).

\section{Discussion}

Diatoms exported out from the photic zone (2.2 $( \pm 5.6) 10^{6}$ valves $\left.\mathrm{m}^{-2} \mathrm{~d}^{-1}\right)$, similar to those registered in other coastal upwelling systems (Sancetta, 1995; Lange et al., 1998; Romero et al., 2002; Abrantes et al., 2002; Venrick et al., 2003; Onodera et al., 2005), showed contrasting results compared to diatom abundances on the surface waters (Figs. 3c, 5c and e). In fact, the a priori contradictory observation of maximum diatom fluxes during autumn-winter when irradiance conditions were unfavorable for phytoplankton growth and Chl $a$ showed minimum levels (Figs. 2, 3c and 5e), can be explained by the input of allochthonous sources associated with the inner continental margin hydrodynamics (Zúñiga et al., 2016). Furthermore,
Zúñiga et al. (2016) have also showed how seasonal intensification of primary production promoted biogenic settling particles during spring-summer seasons, clarifying why diatom assemblages' dominant species recorded in the trap material were the same as in the water column (Figs. 4 and 7). With this in mind, our results confirm the major influence of both hydrodynamic and biogenic processes over the diatoms abundance, assemblage composition and export in this coastal upwelling system.

\subsection{Sediment trap diatom assemblage as a tracer for allochthonous sources in sinking material}

During highly hydrodynamic downwelling periods, higher wave heights, indicative of strong storms, co-occurred with maximum fluxes of benthic diatoms (Figs. 2c and 6a), whose natural habitat is the sediment interface. This finding, along with the fact that during these high-energy episodes lithogenic particle fluxes achieved their maximum levels (as shown in Zúñiga et al., 2016), may only be explained if strong storms resuspended surface sediments covering the Iberian continental shelf (Dias et al., 2002; Vitorino et al., 2002; Jouanneau et al., 2002; Oberle et al., 2014). Furthermore, stormy conditions were accompanied by intense Minho and Douro river discharge which impacted the water column thermohaline structure (Fig. 2c and d). The increase in FW diatoms associated with river runoff reinforce that those continental inputs are an additional source of terrestrial material to the inner continental shelf (Figs. 2d and 6c). Indeed, canonical analysis of sediment trap samples revealed a high correlation between benthic and FW diatoms, corroborating the co-occurrence of both resuspension processes and river discharge during downwelling periods (Fig. 8 and Table 2).

Additional evidence of resuspension resulted from the analysis of the marine diatom assemblage collected in the sediment trap. Paralia sulcata was sporadically found in the water column diatom assemblage during the 2009-2012 studied years (Fig. 4c and Table 3). This meroplanktonic and shadow species was, by contrast, common in sediments and contributed significantly to the trap diatom fluxes during downwelling phases (Fig. 7c and Table 3). All this indicates that this resistant-to-dissolution species can be easily resuspended from the sediments under highly hydrodynamic conditions (Bernárdez et al., 2010; Zúñiga et al., 2011). This is also supported by the positive relationship found between Paralia sulcata and benthic diatoms in the trap samples (Fig. 8 and Table 2).

Also of interest is the positive correlation between FW and benthic diatoms to Thalassiosira eccentrica (Table 2), a species which is known to occur in areas where nutrient input is continuous throughout the year, such as in areas influenced by river discharge (Moita, 1993; Abrantes and Moita, 1999). 


\subsection{Seasonal succession of diatom species during upwelling seasons: the imprint of the fossil diatom assemblage}

During the studied period, the water column diatom community was modulated by the seasonality of environmental variables, with the highest abundances always recorded during upwelling periods, when irradiance and water column characteristics promote favorable conditions for diatom growth (Figs. 2 and 3). In this regard, a detailed analysis of the marine diatom assemblage as a whole revealed that most living diatom species linked to upwelling favorable conditions were either not present (e.g., Asterionellopsis glacialis, Detonula pumila, Guinardia delicatula and Skeletonema costatum) or appeared with a significantly lower contribution (e.g., Nitzschia spp., Pseudo-nitzschia spp. and small centric) in the diatom assemblages in both the sediment trap and the surface sediment samples (Table 3). This confirms that selective dissolution processes acted on thinwalled, less-silicified diatoms and, thus, only the robust and heavily silicified frustules and resting spores will be available to be exported and buried. Although this may lead to underestimation of primary production from fossil diatoms, analysis made over the sediment trap data demonstrates that the vertical sinking of the highly resistant Chaetoceros and Leptocylindrus spp. resting spores (positively positioned in CCA1) (Fig. 8) occurred in agreement with their dominance in the upper water column, and therefore both diatom genera are good sedimentary indicators of high primary production in the NW Iberian margin. This brings new relevant information to previous works carried out along this margin, which have only considered Chaetoceros spp. resting spores as a tracer of the coastal upwelling regime (Abrantes, 1988; Bao et al., 1997; Abrantes and Moita, 1999).

Furthermore, during the highly productive upwelling periods, we found how the environmentally controlled succession between Chaetoceros and Leptocylindrus spp. blooms (Figueiras and Rios, 1993; Escaravage et al., 1999; Casas et al., 1999; Nogueira and Figueiras, 2005) is clearly reflected in the export of their corresponding resting spores (Figs. 4, 7 and 8). Indeed, our sediment trap dataset reflected how the sinking fluxes of Chaetoceros spp. resting spores were mostly associated with the onset of the upwelling period, when irradiance conditions are favorable and persistent northerly winds lead to the upwelling of nutrient-rich subsurface ENACW waters on the shelf (Figs. 3, 4, 7 and 8). In contrast, Leptocylindrus spp. resting spore fluxes were significantly associated with late-summer and autumn when more frequent relaxation of winds promoted water column stratification and nutrient depletion (Figs. 3, 4, 7 and 8). In this regard, our finding linking environmentally controlled diatom blooms and resting spores' vertical export give us the opportunity to reinterpret previous studies published on this margin with regards upwelling-related paleosignals, where, despite not being discussed, a downcore alternation between the resting spores accumulation rates of these two genera is shown (Bernárdez et al., 2008; Abrantes et al., 2011).

\section{Conclusions}

Even though the remobilization of bottom sediments by resuspension processes may distort diatoms accumulation and preservation rates in the NW Iberian margin, our results prove that surface sediments from the inner continental shelf integrate both hydrodynamic and biological processes occurring in the upper water column (Fig. 8). This provides relevant information in relation to the use of fossil diatoms in marine sediment records for determining allochthonous sources and primary production paleosignals in this margin. Main observations may be summarize as follows: (i) high diatom fluxes during downwelling periods did not represent water column primary production signal but rather reflected highly energetic episodes that proved that resuspended sediment and river inputs were the main sources of diatoms to the sinking fluxes. This fact is also evidenced by the significant increase of both benthic and freshwater diatoms in the sediment trap assemblage. (ii) During highly productive upwelling periods, diatom's export signal, mainly represented by the highly resistant-to-dissolution Chaetoceros and Leptocylindrus spp. resting spores, mirrored diatom community structure in the upper water column, and thus both diatom genera may be considered as good sedimentary imprints of highly productive upwelling conditions. (iii) The seasonal succession as a response to particular environmental conditions in both the bloom and export of Chaetoceros and Leptocylindrus spp. postulates that contributions of these diatom genera to the total marine diatom assemblage in the sediment records should allow the identification of paleoceanographic conditions attributed to different patterns (onset versus relaxation) of the upwelling regime. 


\section{Appendix A}

Table A1. List of diatom species found in both the RAIA sediment trap and surficial sediment sample (Geo B 11002). Species that appeared in more than one sediment trap sample with a percentage higher than $2 \%$ of the total abundance are highlighted in bold. Ecology preferences: B is benthic; $\mathrm{MP}$ is meroplanktonic; $\mathrm{P}$ is planktonic; $\mathrm{CO}$ is coastal; $\mathrm{O}$ is open ocean; $\mathrm{C}$ is cosmopolitan; $\mathrm{M}$ is marine; $\mathrm{MB}$ is marine to brackish; $\mathrm{BF}$ is brackish to freshwater; $\mathrm{BR}$ is brackish; FW is freshwater.

\begin{tabular}{|c|c|c|c|}
\hline Diatom species & Ecology & $\begin{array}{l}\text { Sediment } \\
\text { trap }\end{array}$ & Sediments \\
\hline Achnanthes brevipes $\mathrm{C}$. Agardh & B-MB & $x$ & $x$ \\
\hline Achnanthes sp. (cf. FW) & $\mathrm{B}-\mathrm{FW}$ & $\times$ & \\
\hline Actinocyclus curvatulus Janisch & $\mathrm{P}-\mathrm{M}-\mathrm{C}$ & $x$ & $x$ \\
\hline Actinocyclus octonarius Ehrenberg & $\mathrm{P}-\mathrm{M}-\mathrm{C}$ & $\times$ & \\
\hline Actinoptychus senarius (Ehrenberg) Ehrenberg & MP-C & $x$ & $x$ \\
\hline Actinocyclus sp. & $x$ & $\times$ & \\
\hline Amphora gracilis Ehrenberg & B-FW & $x$ & \\
\hline Amphora marina T. V. Desikachary and P. Prema & $\mathrm{B}-\mathrm{MB}$ & $x$ & \\
\hline Amphora sp. & $\mathrm{B}$ & $\times$ & \\
\hline Anorthoneis excentrica (Donkin) Grunow & $\mathrm{B}-\mathrm{M}$ & $\times$ & \\
\hline Asteromphalus flabellatus (Brébisson) Greville & $\mathrm{P}-\mathrm{M}$ & $x$ & \\
\hline Asteromphalus sp. & $\mathrm{P}-\mathrm{M}-\mathrm{O}$ & $x$ & \\
\hline Aulacoseira cf. granulata (Ehrenberg) Simonsen & P-FW & $\times$ & $\times$ \\
\hline Aulacoseira sp. & $\mathrm{P}-\mathrm{FW}$ & $x$ & $x$ \\
\hline Azpeitia neocrenulata (VanLandingham) (G. Fryxell and T. P. Watkins) & $\mathrm{P}-\mathrm{M}$ & $\times$ & \\
\hline Azpeitia nodulifera (A. Schmidt) G. A. Fryxell and P. A.Sims & $\mathrm{P}-\mathrm{M}$ & $x$ & \\
\hline Bacillaria paxillifera (O. F. Müller) T.Marsson & B-P-M & $\times$ & \\
\hline Bacteriastrum hyalinum Lauder & P-M & $\times$ & \\
\hline Caloneis sp. & $\mathrm{B}-\mathrm{MB}$ & $\times$ & \\
\hline Campylodiscus incertus A. W. F. Schmidt & $\mathrm{P}-\mathrm{M}$ & $x$ & \\
\hline Campyloneis grevillei (W. Smith) Grunow and Eulenstein & B-M & $x$ & \\
\hline Campylosira cymbelliformis Grunow ex Van Heurck & $\mathrm{B}-\mathrm{MB}-\mathrm{CO}$ & $\times$ & \\
\hline Catacombas gaillonii (Bory) D. M. Williams and Round & B-M & $\times$ & \\
\hline Cerataulus smithii Ralfs ex Pritchard & $\mathrm{B}-\mathrm{MB}$ & $x$ & \\
\hline Chaetoceros lorenzianus Grunow & $\mathrm{P}-\mathrm{M}-\mathrm{CO}$ & $\times$ & \\
\hline Chaetoceros sp. & $\mathrm{P}-\mathrm{M}-\mathrm{CO}$ & $\times$ & \\
\hline Chaetoceros sp. (resting spores) & $\mathrm{M}-\mathrm{CO}$ & $\times$ & $\times$ \\
\hline Cocconeis disculoides (Hustedt) Stefano and Marino & B-M & $\times$ & \\
\hline Cocconeis guttata Husted and Aleem & $\mathrm{B}-\mathrm{M}$ & $x$ & \\
\hline Cocconeis hoffmannii Simonsen & B-M & $x$ & \\
\hline Cocconeis neodiminuta Krammer & B-FW & $x$ & \\
\hline Cocconeis placentula Ehrenberg & B-FW & $x$ & $x$ \\
\hline Cocconeis pseudomarginata Gregory & B-M & $x$ & \\
\hline Cocconeis scutellum Ehrenberg & $\mathrm{B}-\mathrm{M}$ & $\times$ & $\times$ \\
\hline Cocconeis speciosa Gregory & $\mathrm{B}-\mathrm{M}$ & $\times$ & \\
\hline Cocconeis stauroneiformis (W. Smith) H. Okuno & $\mathrm{B}-\mathrm{M}$ & $\times$ & \\
\hline Cocconeis sp. & $\mathrm{B}$ & $\times$ & \\
\hline Coscinodiscus gigas Ehrenberg & $\mathrm{P}-\mathrm{M}$ & $\times$ & \\
\hline Coscinodiscus marginatus Ehrenberg & $\mathrm{P}-\mathrm{M}-\mathrm{OC}$ & $x$ & $x$ \\
\hline Coscinodiscus cf. oculus-iridis (Ehrenberg) Ehrenberg & $\mathrm{P}-\mathrm{M}-\mathrm{OC}$ & $x$ & \\
\hline Coscinodiscus radiatus Ehrenberg & $\mathrm{P}-\mathrm{M}-\mathrm{OC}$ & $\times$ & $\times$ \\
\hline Coscinodiscus sp. & $\mathrm{P}-\mathrm{M}$ & $x$ & \\
\hline Ctenophora pulchella (Ralfs ex Kützing) & $\mathrm{P}-\mathrm{BF}$ & $\times$ & \\
\hline Cyclotella meneghiniana Kützing & $\mathrm{P}-\mathrm{CO}-\mathrm{BF}$ & $x$ & $x$ \\
\hline Cyclotella plitvicensis Husted & P-FW & $\times$ & \\
\hline Cyclotella stelligera Cleve and Grunow in Van Heurck & $\mathrm{P}-\mathrm{FW}$ & $x$ & \\
\hline Cyclotella radiosa (Grunow) Lemmermann & $\mathrm{P}-\mathrm{FW}$ & $x$ & \\
\hline Cyclotella sp. & $\mathrm{P}-\mathrm{FW}$ & $\times$ & \\
\hline Cyclostephanos sp. & $\mathrm{P}$ & $x$ & \\
\hline Cymbella affinis Kützing & B-FW & $\times$ & $\times$ \\
\hline Cymbela sp. & $\mathrm{B}$ & $\times$ & \\
\hline
\end{tabular}


Table A1. Continued.

\begin{tabular}{|c|c|c|c|}
\hline Diatom species & Ecology & $\begin{array}{l}\text { Sediment } \\
\text { trap }\end{array}$ & Sediments \\
\hline Delphineis minutissima (Husted) Simonsen & $\mathrm{P}-\mathrm{M}-\mathrm{CO}$ & $x$ & $x$ \\
\hline Delphineis surirella (Ehrenberg) G. W. Andrews & $\mathrm{P}-\mathrm{M}-\mathrm{CO}$ & $\times$ & \\
\hline Detonula pumila (Castracane) Gran & $\mathrm{P}-\mathrm{M}-\mathrm{CO}$ & $\times$ & \\
\hline Dimeregramma minor (Gregory) Ralfs ex Pritchard & $\mathrm{B}-\mathrm{M}$ & $x$ & \\
\hline Diploneis cf. bombus (Ehrenberg) Ehrenberg & $\mathrm{B}-\mathrm{MB}$ & $x$ & $\times$ \\
\hline Diploneis didymus (Ehrenberg) Ehrenberg & B-MB-BFW & $\times$ & \\
\hline Diploneis smithii (Brébisson) Cleve & B-MB-BFW & $\times$ & \\
\hline Diploneis cf. stroemii Husted & $\mathrm{B}-\mathrm{M}$ & $x$ & \\
\hline Diploneis suborbicularis (W. Gregory) Cleve & B-M & $x$ & \\
\hline Diploneis weissflogii (A. W. F. Schmidt) Cleve & B-M & $x$ & \\
\hline Diploneis sp. & $\mathrm{B}$ & $\times$ & \\
\hline Dytilum sp. & $\mathrm{P}-\mathrm{M}-\mathrm{CO}$ & $\times$ & \\
\hline Encyonema sp. & $\mathrm{B}-\mathrm{FW}$ & $\times$ & \\
\hline Epithemia sp. & B-BFW & $x$ & \\
\hline Eunotia cf. pectinalis (Kützing) Rabenhorst & B-FW & $\times$ & \\
\hline Eunotia praerupta (Grunow) & $\mathrm{B}-\mathrm{FW}$ & $\times$ & \\
\hline Eunotia sp. & $\mathrm{B}-\mathrm{FW}$ & $\times$ & \\
\hline Fragilariforma constricta (Ehrenberg) D. M. Williams and Round & $\mathrm{B}-\mathrm{FW}$ & $\times$ & \\
\hline Fragilaria crotonensis (Kitton) Cleve and Möller & B-BFW & $\times$ & \\
\hline Fragilaria inflata (Heiden) Hustedt & B-FW & $x$ & \\
\hline Fragilaria investiens (W. Smith) Clever-Euler & B-M & $\times$ & \\
\hline Fragilaria schulzii Brockmann & B-M & $\times$ & \\
\hline Fragilaria sp. & $\mathrm{B}-\mathrm{C}$ & $\times$ & \\
\hline Fragilariforma virescens (Ralfs) D. M. Williams and Round & B-P-FW & $\times$ & \\
\hline Gomphonema sp. & $\mathrm{B}$ & $\times$ & $\times$ \\
\hline Gomphonema cf. acuminatum (Ehrenberg) & B-BFW & $\times$ & \\
\hline Gomphonema cf. constrictum (Ehrenberg) & $\mathrm{B}-\mathrm{FW}$ & $\times$ & \\
\hline Gomphonema parvulum (Kützing) Kützing & $\mathrm{B}-\mathrm{FW}$ & $x$ & \\
\hline Grammatophora angulosa (Ehrenberg) & $\mathrm{B}-\mathrm{M}$ & $\times$ & \\
\hline Grammatophora marina (Lyngbye) Kützing & B-M & $\times$ & $\times$ \\
\hline Grammatophora oceanica (Ehrenberg) Cleve & B-M & $x$ & \\
\hline Grammatophora sp. & B-M & $x$ & \\
\hline Grammatophora serpentina (Ehrenberg) Hartley & B-M & $\times$ & \\
\hline Haslea sp. & B-P-M-MB & $\times$ & \\
\hline Hantzschia sp. & B-M-MB & $x$ & \\
\hline Hemidiscus cuneiformis Wallich & P-M-O & $\times$ & \\
\hline Hemiaulus sp. & $\mathrm{P}-\mathrm{M}-\mathrm{CO}$ & $x$ & \\
\hline Hyalodiscus scoticus (Kützing) Grunow & $\mathrm{P}-\mathrm{M}-\mathrm{CO}$ & $x$ & \\
\hline Leptocylindrus sp. (resting spores) & $\mathrm{M}-\mathrm{CO}$ & $x$ & $x$ \\
\hline Licmophora abbreviata (C.Agardh) & B-M & $\times$ & \\
\hline Licmophora sp. & B-M & $x$ & \\
\hline Luticola mutica (Kützing) D. G. Mann & $\mathrm{B}-\mathrm{FW}$ & $x$ & \\
\hline Martyana martyi (Héribaud-Joseph) Round & B-BR-FW & $x$ & \\
\hline Melosira moniliformis (O. F. Müller) C.Agardh & B-M & $\times$ & \\
\hline Melosira varians C.Agardh & $\mathrm{P}-\mathrm{FW}$ & $\times$ & \\
\hline Melosira westii W. Smith & $\mathrm{P}-\mathrm{M}-\mathrm{CO}$ & $x$ & $x$ \\
\hline Melosira sp. & B-P-M-BR-FW & $x$ & $\times$ \\
\hline Navicula bacillum Ehrenberg & B-P-M-CO & $\times$ & \\
\hline Navicula cf. cancellata Donkin & $\mathrm{B}-\mathrm{P}-\mathrm{M}-\mathrm{CO}$ & $x$ & \\
\hline Navicula cincta (Ehrenberg) Ralfs & B-FW & $x$ & \\
\hline Navicula mutica Kützing & $\mathrm{B}-\mathrm{FW}$ & $x$ & \\
\hline Navicula cf. pennata A. Schmidt & B-P-M-CO & $x$ & \\
\hline Navicula sp. & $\mathrm{B}-\mathrm{P}$ & $\times$ & \\
\hline Nitzschia angularis W. Smith & $\mathrm{P}-\mathrm{M}-\mathrm{CO}$ & $\times$ & \\
\hline Nitzschia longissima (Brébisson) Ralfs & $\mathrm{P}-\mathrm{M}$ & $\times$ & \\
\hline
\end{tabular}


Table A1. Continued.

\begin{tabular}{|c|c|c|c|}
\hline Diatom species & Ecology & $\begin{array}{l}\text { Sediment } \\
\text { trap }\end{array}$ & Sediments \\
\hline Nitzschia macilenta W. Gregory & $\mathrm{M}-\mathrm{CO}$ & $\times$ & \\
\hline Nitzschia marina Grunow & P-M & $x$ & $\times$ \\
\hline Nitzschia umbonata (Ehrenberg) H. Lange-Bertalot & M-FW & $\times$ & \\
\hline Nitzschia sp. & P-M-O & $\times$ & $x$ \\
\hline Odontella aurita (Lyngbye) C. Agardh & $\mathrm{P}-\mathrm{M}-\mathrm{CO}$ & $\times$ & \\
\hline Odontella longicruris (Greville) M. A. Hoban & $\mathrm{P}-\mathrm{M}-\mathrm{CO}$ & $\times$ & \\
\hline Odontella sp. & P-M & $\times$ & \\
\hline Opephora marina (W. Gregory) Petit & B-M & $x$ & \\
\hline Paralia sulcata (Ehrenberg) Cleve & $\mathrm{MP}-\mathrm{CO}$ & $\times$ & $\times$ \\
\hline Petroneis humerosa (Brébisson ex W.Smith) Stickle and D. G. Mann & B-M & $\times$ & \\
\hline Pinnularia borealis Ehrenberg & $\mathrm{B}-\mathrm{FW}$ & $\times$ & \\
\hline Pinnularia sp. & B & $\times$ & \\
\hline Pleurosigma elongatum W. Smith & P-BR & $\times$ & \\
\hline Pleurosigma normanii Ralfs in Pritchard & $\mathrm{P}-\mathrm{M}$ & $\times$ & \\
\hline Pleurosigma sp. & $\mathrm{P}$ & $\times$ & \\
\hline Pleurosira laevis (Ehrenberg) Compère & P-BR & $\times$ & \\
\hline Porosira glacialis (Grunow) Jørgensen & P-BR & $\times$ & \\
\hline Podosira stelliger (Bailey) Mann & P-M & $\times$ & $\times$ \\
\hline Proboscia alata (Brightwell) Sundström) & $\mathrm{P}-\mathrm{M}$ & $\times$ & \\
\hline Psammodiscus nitidus (Gregory) Round and Mann & MP-M-CO & $x$ & \\
\hline Pseudo-nitzschia pungens (Grunow ex Cleve) G. R. Hasle & P-M-C & $\times$ & \\
\hline Pseudo-nitzschia seriata (Cleve) H. Peragallo & P-M & $\times$ & \\
\hline Rhaphoneis amphiceros (Ehrenberg) Ehrenberg & B-M & $\times$ & \\
\hline Rhabdonema arcuatum (Lyngbye) Kützing & B-M & $\times$ & \\
\hline Rhabdonema minutum Kützing & B-M & $\times$ & \\
\hline Rhabdonema sp. & B-M & $\times$ & \\
\hline Rhizosolenia bergonii Peragallo & P-M-O & $\times$ & \\
\hline Rhizosolenia hebetata (Bailey) Gran & P-M-O & $\times$ & \\
\hline Rhizosolenia sp. & $\mathrm{P}-\mathrm{M}-\mathrm{O}$ & $\times$ & \\
\hline Rhoicosphenia abbreviata (C. Agardh) Lange-Bertalot & B-BR-FW & $\times$ & \\
\hline Rhoicosphenia marina (Kützing) M. Schmidt & $\mathrm{B}-\mathrm{M}-\mathrm{CO}$ & $\times$ & \\
\hline Roperia tesselata (Roper) Grunow ex Pelletan & $\mathrm{P}-\mathrm{M}-\mathrm{O}$ & $\times$ & $\times$ \\
\hline Staurosirella pinnata (Ehrenberg) D. M. Williams and Round & MP-FW & $\times$ & \\
\hline Staurosirella sp. & & $\times$ & \\
\hline Stellarima stellaris (Roper) G. R. Hasle and P. A. Sims & $\mathrm{P}-\mathrm{M}$ & $\times$ & \\
\hline Stephanodiscus astrea (Ehrenberg) Grunow & $\mathrm{P}-\mathrm{C}$ & $\times$ & \\
\hline Stephanodiscus sp. & $\mathrm{P}-\mathrm{C}$ & $\times$ & $\times$ \\
\hline Stephanopyxis turris (Greville) Ralfs in Pritchard & $\mathrm{P}-\mathrm{M}$ & $\times$ & \\
\hline Surirella sp. & B-M-BR & $\times$ & \\
\hline Synedra sp. & & $\times$ & \\
\hline Ulnaria ulna (Nitzsch) Compère & $\mathrm{B}-\mathrm{FW}$ & $\times$ & $\times$ \\
\hline Tabellaria fenestrata (Lyngbye) Kützing & $\mathrm{B}-\mathrm{FW}$ & $\times$ & \\
\hline Tabellaria flocculosa (Roth) Kützing & $\mathrm{B}-\mathrm{FW}$ & $\times$ & \\
\hline Tabellaria sp. & & $\times$ & \\
\hline Tetracyclus glans (Ehrenberg) F. W. Mills & $\mathrm{B}-\mathrm{FW}$ & $\times$ & \\
\hline Thalassiosira eccentrica (Ehrenberg) Cleve & $\mathrm{P}-\mathrm{M}-\mathrm{O}$ & $\times$ & $\times$ \\
\hline Thalassiosira cf. leptopus (Grunow) Hasle and G. Fryxell P-M-O & $x$ & $\times$ & \\
\hline Thalassiosira lineata Jousé & $\mathrm{P}-\mathrm{M}-\mathrm{O}$ & $x$ & \\
\hline Thalassiosira sp. & $\mathrm{P}$ & $\times$ & $\times$ \\
\hline Thalassionema nitzschioides (Grunow) Mereschkowsky & $\mathrm{P}-\mathrm{M}$ & $\times$ & $\times$ \\
\hline Toxarium undulatum Bailey & $\mathrm{P}-\mathrm{M}$ & $x$ & \\
\hline Trachyneis aspera (Ehrenberg) Cleve 1894 & B-M-BR & $\times$ & $x$ \\
\hline Triceratium favus Ehrenberg & P-M & $\times$ & \\
\hline Tryblionella angustata W. Smith & $\mathrm{P}-\mathrm{M}$ & $\times$ & \\
\hline Tryblionella navicularis (Brébisson) Ralfs & B-BR & $\times$ & \\
\hline
\end{tabular}


Competing interests. The authors declare that they have no conflict of interest.

Acknowledgements. The authors gratefully thank the crew of R/V Mytilus for their valuable help during the cruises. The authors also want to specially recognize specific lab work made from different members of both the Oceanography group from the Instituto de Investigaciones Marinas de Vigo (CSIC) and the Divisão de Geologia e Georecursos Marinhos from Instituto Português do Mar e da Atmosfera (IPMA). Special thanks to M. Zúñiga for his help in the writing process. This study was sponsored by CAIBEX (CTM2007-66408-C02-01/MAR) and REIMAGE (CTM2011-30155-C03-03) projects funded by the Spanish Government, EXCAPA project (10MDS402013PR) supported by Xunta de Galicia, the EU FEDER funded projects RAIA (INTERREG 2009/2011-0313/RAIA/E) and RAIA.co (INTERREG 2011/2013-052/RAIA.co/1E) and the CALIBERIA project (PTDC/MAR/102045/2008) financed by Fundação para a Ciência e a Tecnologia (FCT-Portugal) and COMPETE/FEDER -FCOMP01-0124-FEDER-010599. Diana Zúñiga and Emilia Salgueiro were funded by a postdoctoral fellowship (Plan I2C) from Xunta de Galicia (Spain) and (SFRH/BPD/111433/2015) from FCT, respectively. Celia Santos was funded by a doctoral grant from FCT (Portugal) (SFRH/BD/88439/2012).

Edited by: L. de Nooijer

Reviewed by: two anonymous referees

\section{References}

Abrantes, F.: Diatoms assemblages as upwelling indicators in surface sediments in Portugal, Mar. Geol., 85, 15-39, 1988.

Abrantes, F. and Moita, M. T.: Water column and recent sediment data on diatoms and coccolithophorids, off Portugal, confirm sediment record of upwelling events, Oceanol. Acta, 22, 67-84, 1999.

Abrantes, F., Meggers, H., Nave, S., Bollman, J., Palma, S., Sprengel, C., Henderiks, J., Spies, A., Salgueiro, E., Moita, T., and Neuer, S.: Fluxes of micro-organisms along a productivity gradient in the Canary Islands region $\left(29^{\circ} \mathrm{N}\right)$ : implications for paleoreconstructions, Deep-Sea Res. Pt. II, 49, 3599-3629, 2002.

Abrantes, F., Gil, I., Lopes, C., and Castro, M.: Quantitative diatom analyses: a faster cleaning procedure, Deep-Sea Res. Pt. II, 52, 189-198, 2005.

Abrantes, F., Rodrigues, T., Montanari, B., Santos, C., Witt, L., Lopes, C., and Voelker, A. H. L.: Climate of the last millennium at the southern pole of the North Atlantic Oscillation: an innershelf sediment record of flooding and upwelling, Clim. Res., 48, 261-280, 2011.

Álvarez-Salgado, X. A., Figueiras, F. G., Pérez, F. F., Groom, S., Nogueira, E., Borges, A. V., Chou, L., Castro, C. G., Moncoiffé, G., Ríos, A. F., Miller, A. E. J., Frankignoulle, M., Savidge, G., and Wollast, R.: The Portugal coastal counter current off NW Spain: new insights on its biogeochemical variability, Prog. Oceanogr., 56, 281-321, 2003.

Bakun, A.: Coastal upwelling Indices, West Coast of North America, 1946-71, US Department of Commerce, National Oceanic and Atmospheric Administration, National Marine Fisheries Service, Seattle, WA, 1973.

Bao, R., Varela, M., and Prego, R.: Mesoscale distribution patterns of diatoms in surface sediments as tracers of coastal upwelling of the Galician shelf (NW Iberian Peninsula), Mar. Geol., 144, 117-130, 1997.

Battarbee, R. W.: A new method for estimating absolute microfossil numbers with special reference to diatoms, Limnol. Oceanogr., 18, 647-653, 1973.

Bernárdez, P., Prego, R., Varela, M., and Francés, G.: Diatom thanatocoenosis in a middle Galician Ría: Spatial patterns and their relationship to the seasonal diatom cycle in the water column and hydrographic conditions, Cont. Shelf Res., 28, 2496-2508, 2008.

Bernárdez, P., Varela, M., Pazos, Y., Prego, R., and Francés, G.: Biocenosis and thanatocoenosis of diatoms in a western Galician ría, J. Plankton Res., 32, 857-883, 2010.

Capone, D. G. and Hutchins, D. A.: Microbial biogeochemistry of coastal upwelling regimes in a changing ocean, Nature, 6, 711717, 2013.

Castro, C. G., Álvarez-Salgado, X. A., Figueiras, F. G., Pérez, F. F., and Fraga, F.: Transient hydrographic and chemical conditions affecting microplankton populations in the coastal transitions zone of the Iberian upwelling system (NW Spain) in September 1986, J. Mar. Res., 55, 321-352, 1997.

Castro, C. G., Nieto-Cid, M., Álvarez-Salgado, X. A., and Pérez, F. F.: Local remineralization patterns in the mesopelagic zone of the Eastern North Atlantic, off the NW Iberian Peninsula, Deep-Sea Res. Pt. I, 53, 1925-1940, 2006.

Casas, B., Varela, M., and Bode, A.: Seasonal succession of phytoplakton species on the coast of A Coruña (Galicia, Northwest Spain), Boletín del Instituto Español de Oceanografía, 15, 413429, 1999.

Dias, J. M. A., González, R., García, C., and Díaz-del-Río, V.: Sediment distribution patterns on the Galicia-Minho continental shelf, Prog. Oceanogr., 52, 215-231, 2002.

Dormann, C. F., Elith, J., Bacher, S., Buchmann, C., Carl, G., Carré, G., García Marquéz, J. R., Gruber, B., Lafourcade, B., Leitao, P. J., Munkemüller, T., McClean, C., Osborne, P. E., Reineking, B., Schröder, B., Skidmore, A. K., Zurell, D., and Lautenbach, S.: Collinearity: a review of methods to deal with it and a simulation study evaluating their performance, Ecography, 36, 27-46, 2013.

Escaravage, V., Prins, T. C., Nijdam, C., Smaal, A. C., and Peeters, J. C. H.: Response of phytoplankton communities to nitrogen input reduction in mesocosm experiments, Mar. Ecol.-Prog. Ser. 179, 187-199, 1999.

Espinoza-González, O., Figueiras, F. G., Crespo, B., Teixeira, I. G., and Castro, C. G.: Autotrophic and heterotrophic microbial plankton biomass in the NW Iberian upwelling: seasonal assessment of metabolic balance, Aquat. Microb. Ecol., 67, 77-89, 2012.

Falkowski, P. G., Barber, R. T., and Smetacek, V.: Biogeochemical controls and feedbacks on ocean primary production, Science, 281, 200-206, doi:10.1126/science.281.5374.200, 1998.

Fatela, F. and Taborda, R.: Confidence limits of species proportions in microfossil assemblages, Mar. Micropaleontol., 45, 169-174, 2002.

Figueiras, F. G. and Pazos, Y.: Microplankton assemblages in three Rías Baixas (Vigo, Arosa and Muros, Spain) with a subsurface 
chlorophyll maximum: their relationships to hydrography, Mar. Ecol.-Prog. Ser., 76, 219-233, 1991.

Figueiras, F. G. and Rios, A. F.: Phytoplankton succession, red tides and the hydrographic regime in the Rias Bajas of Galicia, in: Toxic Phytoplankton Blooms in the Sea, edited by: Smayda, T. J. and Shimizu, Y., Elsevier Science Publishers B.V., 239-244, 1993.

Figueiras, F. G., Labarta, U., and Fernández Reiriz, M. J.: Coastal upwelling, primary production and mussel growth in the Rías Baixas of Galicia, Hydrobiologia, 484, 121-131, 2002.

Fiuza, A. F. G.: Hidrologia e dinâmica das águas costeiras de Portugal, PhD Thesis, Facultade de Ciencias, Univ. Lisboa, Portugal, 1984.

Fraga, F.: Upwelling off the Galician coast, nothwest of Spain, in: Coastal Upwelling, edited by: Richards, F., American Geophysical Union, Washington, 176-182, 1981.

Hansen, H. P. and Grasshoff, K.: Automated chemical analysis, in: Methods of seawater analysis, edited by: Grasshoff, K., Ehrhadt, M., and Kremling, K., Verlag Chemie, Weinheim, 347-395, 1983.

Haynes, R. and Barton, E. D.: A poleward flow along the Atlantic coast of the Iberian Peninsula, J. Geophys. Res., 95, 1142511442, 1990.

Jouanneau, J. M., Weber, O., Drago, T., Rodrigues, A., Oliveira, A., Dias, J. M. A., Garcia, S., Schmidt, S., and Reyss, J. L.: Recent sedimentation and sedimentary budgets on the wester Iberian shelf, Prog. Ocenogr., 52, 261-275, 2002.

Lange, C. B., Romero, O. E., Wefer, G., and Gabric, A. J.: Offshore influence of coastal upwelling off Mauritania, NW Africa, as recorded by diatoms in sediment traps at $2195 \mathrm{~m}$ water depth, Deep-Sea Res. Pt. I, 45, 985-1013, 1998.

Moita, T.: Spatial variability of phytoplankton communities in the upwelling region off Portugal, Proceedings of the International Council for the Exploration of the Sea, 64, 1-20, 1993.

Mortlock, R. A. and Froelich, P. N.: A simple method for the rapid determinations of biogenic opal in pelagic marine sediments, Deep-Sea Res., 36, 1415-1426, 1989.

Nogueira, E. and Figueiras, F. G.: The microplankton succession in the Ría de Vigo revisited: species assemblages and the role of weather-induced, hydrodynamic variability, J. Marine Syst., 54, 139-155, 2005.

Oberle, F. K. L., Storlazzi, C. D., and Hanebuth, T. J. J.: Wavedriven sediment mobilization on a storm-controlled margin, J. Marine Syst., 139, 362-372, 2014

Oksanen, J., Blanchet, F. G., Friendly, M., Kindt, R., Legendre, P., McGlinn, D., Minchin, P. R., O’Hara, R. B., Simpson, G. L., Solymos, P., Stevens, M. H. H., Szoecs, E., and Wagne, H.: Vegan: Community ecology, avaliable at: http://CRAN.R-project. org/package=vegan (last access: 20 March 2016), 2015.

Onodera, J., Takahashi, K., and Honda, M. C.: Pelagic and coastal diatom fluxes and the environmental changes in the northwestern North Pacific during December 1997-May 2000, Deep-Sea Res. Pt. II, 52, 2218-2239, 2005.

Otero, P., Ruiz-Villarreal, M., Peliz, A., and Cabanas, J. M.: Climatology and reconstruction of runoff time series in northwest Iberia: influence in the shelf buoyancy budget off Ría de Vigo, Sci. Mar., 74, 247-266, 2010.

Relvas, P., Barton, E. D., Dubert, J., Oliveira, P. B., Peliz, A., da Silva, J. C. B., and Santos, A. M. P.: Physical oceanography of the western Iberia ecosystem: Latest views and challenges, Prog. Oceanogr., 47, 149-173, 2007.

Romero, O. E. and Armand, L. K.: Marine diatoms as indicators of mordern changes in oceanographic conditions, in: The Diatoms: Applications for the Environmental and Earth Sciences, 2nd Edn., edited by: Smol, J. P. and Stoermer, E. F., Cambridge University Press, 373-400, 2010.

Romero, O. E., Lange, C. B., and Wefer, G.: Interannual variability (1988-1991) of siliceous phytoplankton fluxes off northwest Africa, J. Plankton Res., 24, 1035-1046, 2002.

Sancetta, C.: Processes controlling the accumulation of diatoms in sediments: a model derived from the british columbian fjords, Paleoceanography, 4, 235-251, 1989.

Sancetta, C.: Diatoms in the Gulf of California: seasonal flux patterns and the sediment record for the last 15000 years, Paleoceanography, 10, 67-84, 1995.

Schrader, H. J. and Gersonde, R.: Diatoms and silicoflagellates, Utrecht, Micropaleontol. Bull., 17, 129-176, 1978.

Smetacek, V.: Diatoms and the Ocean Carbon Cycle, Protist, 150, 25-32, 1999.

Tenore, K. R., Alonso-Noval, M., Álvarez-Ossorio, M., Atkinson, L. P., Cabanas, J. M., Cal, R. M., Campos, H. J., Castillejo, E., Chesney, E. J., Gonzalez, N., Hanson, R. B., McClain, C. R., Miranda, A., Roman, M. R., Sanchez, J., Santiago, G., Valdes, L., Varela, M., and Yoder, J.: Fisheries and oceanography off Galicia, NW Spain: Mesoscale spatial and temporal changes in physical processes and resultant patterns of biological productivity, J. Geophys. Res., 100, 10943-10966, 1995.

ter Braak, C. J. F.: Canonical correspondence analysis: a new eigenvector technique for multivariate direct gradient analysis, Ecology, 67, 1167-1179, 1986.

Tréguer, P. J. and De La Rocha, C. L.: The world Ocean Silica Cycle, Annu. Rev. Marine Sci., 5, 477-501, 2013.

Utermöhl, H.: Neue Wege in der quantitativen Erfassung des Planktons (mit besonderer Berücksichtigung des Ultraplanktons), Verh. int. Ver. theor. angew. Limnol., 5, 567-596, 1931.

Utermöhl, H.: Zur Vervollkomnung der quantitativen Phytoplankton-Methodik, Mitt. int. Ver. ther. angew. Limnol., 9, 1-38, 1958.

Venrick, E. L., Reid, F. M., and Lange, C. B.: Siliceous phytoplankton in the Santa Barbara Channel: a seven-year comparison of species in a near-bottom sediment trap and in water samples from the euphotic layer, CalCOFI Rep., Vol. 44, 2003.

Vitorino, J., Oliveira, A., Jouanneau, J. M., and Drago, T.: Winter dynamics on the northern Portuguese shelf. Part 2: bottom boundary layers and sediment dispersal, Prog. Oceanogr., 52, 155-170, 2002.

Walsh, J. J.: Importance of continental margins in the marine biogeochemical cycling of carbon and nitrogen, Nature, 350, 53-55, 1991.

Zúñiga, D., Alonso-Perez, F., Castro, C. G., Arbones, B., and Figueiras, F.: Seasonal contribution of living phytoplankton carbon to vertical fluxes in a coastal upwellig system (Ría de Vigo, NW Spain), Cont. Shelf Res., 31, 414-424, 2011.

Zúñiga, D., Villacieros-Robineau, N., Salgueiro, E., Alonso-Pérez, F., Rosón, G., Abrantes, F., and Castro, C. G.: Particle fluxes in the NW Iberian coastal upwelling system: hydrodynamical and biological control, Cont. Shelf Res., 123, 89-98, 2016. 